\title{
CHANGES IN FREE AMINO ACIDS IN THE PLASMA DURING HEPATIC GOMA
}

\author{
BY CHUNG WU, JESSE L. BOLLMAN, AND HUGH R. BUTT
}

(From the Mayo Clinic and Mayo Fonndation,1 Rochester, Minn.)

(Submitted for publication August 2, 1954; accepted February 23, 1955)

Previous reports from various laboratories have emphasized the failure to demonstrate consistent and significant biochemical changes during hepatic coma (1-3). However, a gross increase of amino acids in the plasma, urine and spinal fluid $(4,5)$ and an elevation of ammonia in the blood (6-9) have been observed to accompany hepatic coma. Since diseases of the liver often result in disturb-

1 The Mayo Foundation, Rochester, Minnesota, is a part of the Graduate School of the University of Minnesota. ances of protein metabolism, which are usually manifested by a change in the concentration of amino acids in the plasma, it was felt that a quantitative study of individual amino acids in patients in various stages of hepatic coma might provide some information to elucidate the relationship between the biochemical and clinical findings. The results of such a study, which are presented in this report, indicate that the content of free amino acids in the blood was usually increased during severe hepatic disease. Increases in some or all of

TABLE I

Summary of the case histories of the patients

\begin{tabular}{|c|c|c|c|c|c|c|}
\hline \multirow[b]{2}{*}{ Case } & \multirow[b]{2}{*}{$\begin{array}{c}\text { Age } \\
\text { (grs.) }\end{array}$} & \multirow[b]{2}{*}{ Sex } & \multicolumn{3}{|c|}{ Coma } & \multirow[b]{2}{*}{ Condition of pattent } \\
\hline & & & $\begin{array}{l}\text { Pre- } \\
\text { coma }\end{array}$ & Light & Deep & \\
\hline 1 & 65 & $\dot{M}$ & $\mathbf{X}$ & & & $\begin{array}{l}\text { Acute viral hepatitis; moderate jaundice; condition fairly } \\
\text { good and patient never beyond drowsy state; complete } \\
\text { recovery. }\end{array}$ \\
\hline 2 & 65 & $\mathbf{M}$ & $\mathbf{X}$ & & & Same as case 1. \\
\hline 3 & 62 & $\mathbf{F}$ & $\mathbf{X}$ & & & $\begin{array}{l}\text { Acute viral hepatitis; deep jaundice; urea measured } 12 \mathrm{mg} \text {. } \\
\text { per } 100 \mathrm{cc} \text {. of blood. }\end{array}$ \\
\hline 4 & 33 & $\mathbf{F}$ & $\mathbf{X}$ & & & $\begin{array}{l}\text { Stricture of common bile duct; appeared normal; some } \\
\text { vomiting and hematemesis (?); stupor day after blood } \\
\text { samples were taken. }\end{array}$ \\
\hline 5 & 54 & $\mathbf{M}$ & & $\mathbf{X}$ & & $\begin{array}{l}\text { Carcinoma of common bile duct; deep jaundice with urea } \\
\text { of } 200 \mathrm{mg} \text {. per } 100 \mathrm{cc} \text {. of blood; electrolytes normal; died } \\
\text { day after blood samples were taken. }\end{array}$ \\
\hline 6 & 33 & $\bar{F}$ & & & $\mathbf{x}$ & $\begin{array}{l}\text { Stricture of common bile duct; deep coma after hemorrhage } \\
\text { died with convulsions next day. }\end{array}$ \\
\hline 7 & 45 & $\mathbf{M}$ & & & $\mathbf{X}$ & $\begin{array}{l}\text { Portal cirrhosis; electrolytes normal; mild jaundice; died } \\
5 \text { days after withdrawal of blood. }\end{array}$ \\
\hline 8 & 33 & $\mathbf{F}$ & & & $\mathbf{x}$ & $\begin{array}{l}\text { Stricture of common duct; normal values for urea and } \\
\text { electrolytes; electroencephalogram showed typical changea } \\
\text { of deep hepatic coma; patient was conscious next day. }\end{array}$ \\
\hline 9 & 41 & $\mathbf{F}$ & & & $\mathrm{x}$ & $\begin{array}{l}\text { Postnecrotic cirrhosis; deep coma; had been given } 300 \mathrm{mg} \text {. } \\
\text { of cortisone day before blood was withdrawn; values for } \\
\text { urea and electrolytes normal; died next day. }\end{array}$ \\
\hline 10 & 62 & $\mathbf{F}$ & & & $\mathrm{X}$ & Acute viral hepatitis; very deep jaundice; died next day. \\
\hline 11 & 32 & $\mathbf{M}$ & & . & $\mathbf{X}$ & $\begin{array}{l}\text { Postnecrotic cirrhosis; had repeated blood transfusions } \\
\text { electrolytes normal; deep jaundice; urea measured } 78 \mathrm{mg} \\
\text { per } 100 \mathrm{cc} \text {. of blood; in deep coma } 20 \text { days before blood } \\
\text { withdrawn; died next day. }\end{array}$ \\
\hline 12 & 34 & $\mathbf{M}$ & & & $\mathbf{X}$ & $\begin{array}{l}\text { Postnecrotic cirrhosis; deep coma after portocaval shunt; } \\
\text { never regained consciousness after operation done } 3 \text { days } \\
\text { before blood was taken; died soon after blood was taken. }\end{array}$ \\
\hline
\end{tabular}


TABLE II

Free amino acids and related compounds of the plasma

\begin{tabular}{|c|c|c|c|c|c|c|c|c|c|c|c|c|c|c|c|}
\hline \multirow[b]{4}{*}{ Compound } & \multirow[b]{4}{*}{ Normalt } & \multicolumn{14}{|c|}{ Hepatic coma* } \\
\hline & & \multicolumn{5}{|c|}{ Precoma } & \multirow{3}{*}{$\begin{array}{c}\text { Light } \\
\text { coma } \\
\text { Case } \\
5\end{array}$} & \multicolumn{8}{|c|}{ Deep coma } \\
\hline & & \multicolumn{4}{|c|}{ Cases } & \multirow{2}{*}{$\begin{array}{c}\text { Amino } \\
\text { acid } \\
\text { increased, } \\
\text { cases, } \\
\text { number }\end{array}$} & & \multicolumn{7}{|c|}{ Cases } & \multirow{2}{*}{$\begin{array}{c}\text { Amino } \\
\text { acid } \\
\text { increased } \\
\text { cases, } \\
\text { number }\end{array}$} \\
\hline & & 1 & 2 & 3 & 4 & & & 6 & 7 & 8 & 9 & 10 & 11 & 12 & \\
\hline Alanine & $\begin{array}{c}36.7 \\
(24.3-50.3)\end{array}$ & 0.7 & 0.9 & 1.6 & 0.8 & i & 0.2 & 0.8 & 0.7 & 0.7 & 1.1 & 3.7 & 2.1 & 8.5 & 3 \\
\hline Cystine & $\begin{array}{c}6.1 \\
(3.5-7.5)\end{array}$ & 1.9 & 3.0 & 1.3 & & 2 & 8.6 & 0.6 & 1.8 & 1.0 & 3.0 & 1.8 & 4.9 & 5.4 & 5 \\
\hline Glutamic acid & $\begin{array}{c}10.1 \\
(8.9-11.4)\end{array}$ & 1.5 & 0.9 & 1.5 & 1.7 & 3 & 2.2 & 0.6 & & 1.4 & 2.5 & 2.7 & 2.6 & 4.0 & 5 \\
\hline Glutamine & $\begin{array}{c}57.7 \\
(46.0-68.2)\end{array}$ & 0.7 & 2.0 & 2.2 & 1.3 & 3 & 0.6 & 1.3 & 1.2 & 1.6 & 1.8 & 3.1 & $\mathbf{5 . 0}$ & 14.6 & 6 \\
\hline Glycine & $\begin{array}{c}32.9 \\
(21.8-46.4)\end{array}$ & 0.6 & 0.9 & 0.4 & 1.0 & 0 & 0.3 & 0.7 & 0.6 & 1.0 & 0.7 & 1.1 & 2.5 & 4.7 & 2 \\
\hline Methionine & $\begin{array}{c}7.9 \\
(5.4-11.4)\end{array}$ & 1.1 & 4.4 & 6.2 & 0.7 & 2 & & 0.8 & 5.0 & 0.8 & 3.5 & 8.8 & 9.2 & 8.5 & 5 \\
\hline Serine & $\begin{array}{c}13.6 \\
(10.3-18.6)\end{array}$ & 0.8 & 0.9 & 0.9 & 1.9 & 1 & 0.9 & 1.1 & & 1.6 & 0.9 & 1.6 & 4.3 & 4.2 & 4 \\
\hline Taurine & $\begin{array}{c}16.2 \\
(10.0-25.6)\end{array}$ & 0.5 & 0.4 & 1.3 & 1.8 & 1 & 2.4 & 0.7 & & 1.0 & 1.0 & 4.2 & 0.5 & 2.9 & 2 \\
\hline Tyrosine & $\begin{array}{c}14.0 \\
(10.7-18.9) \\
\end{array}$ & 1.3 & 2.3 & 7.1 & 2.7 & 3 & 0.6 & 1.7 & 1.1 & 2.5 & 1.6 & 6.4 & 6.1 & 5.1 & 6 \\
\hline $\begin{array}{l}\text { Total amino } \\
\text { acids increased } \\
\text { in each case }\end{array}$ & & 2 & 4 & 5 & 5 & & 3 & 2 & 2 & 4 & 5 & 8 & 8 & 9 & \\
\hline
\end{tabular}

* Expressed as the ratios of values of hepatic coma to average normal values shown in this table. Concentrations of 1.3 times or greater than the normal average for glutamic acid and glutamine, and those of 1.5 times or greater than the normal average are definitely above the normal range, and lower than 0.6 is below the normal range for that amino acid.

†xpressed as micrograms per milliliter of plasma. Values in parentheses indicate ranges of six normal persons used as controls.

the seven amino acids specifically studied, and of taurine and glutamine, were present during hepatic coma, but none appeared to be quantitatively related to the severity of the coma.

\section{MATERIALS AND METHODS}

Twelve patients were studied, of whom four were classified as being in a state of precoma; that is, the patients were depressed and coma developed within the next 24 hours, one in light coma and seven in deep coma (Table I). All were observed during the years 1952 and 1953. Blood samples were withdrawn under the conditions summarized in Table $I$ and in the morning after an overnight fast. No patient was receiving amino acid supplements and none received glucose intravenously during the 12 hours prior to withdrawal of blood samples.

Quantities of protein-free, desalted plasma concentrates equivalent to $250 \mu \mathrm{l}$. of plasma were used in the determination of free amino acids by two-dimensional paper chromatography using phenol: m-cresol and 2,4-lutidine as the solvents (10). The chromatograms were sprayed with an ethanolic ninhydrin solution. Spots of the amino acids to be determined were cut out and the color eluted in a propanol solution. Optical densities of the eluates were measured at $570 \mathrm{~m} \mu$. A chromatogram of amino acids serving as the standards was simultaneously prepared. Recovery of amino acids that had been added to the plasma ranged from 90 to 110 per cent.

\section{RESULTS}

Table II shows the changes in free amino acids of the plasma during hepatic coma. Glutamic acid, glutamine, and tyrosine increased in three of four patients in precoma; cystine and methionine increased in two patients. Glycine was not increased in any of the four patients in precoma and it actually decreased in one patient. Taurine also decreased in two of these four patients. This probably accounts for the failure to observe a change in total $\alpha$-amino nitrogen reported earlier (3). 
In the single case of light coma, only cystine, glutamic acid, and taurine were significantly increased. Glutamine and tyrosine increased in six of the seven patients in deep coma and cystine, glutamic acid and methionine increased in five of the seven. Glycine and taurine increased in only two patients. Methionine increased in two of four patients in precoma while a similar increase was observed in five of seven patients in deep coma. Methionine was increased more frequently among patients in deep coma than among patients in precoma. In all 12 patients, glutamic acid, glutamine, and tyrosine increased most frequently; cystine and methionine followed in frequency. Glycine increased least frequently.

The concentration of urea in the blood of comatose patients was normal (cases 8 and 9), low (case 3 ), or high (cases 5 and 11). No relationship between the concentration of urea in the blood and the concentration of free amino acid in the plasma can be discerned from the data. The concentration of amino acids in the plasma of one patient (case 9) who was given four doses of 75 $\mathrm{mg}$. each of cortisone intramuscularly at 4-hour intervals did not change significantly from the concentration in the plasma of patients who were not receiving cortisone.

The chromatogram (Figure 1) shows that the increase of free amino acids in the plasma of a patient (case 11) in deep coma was not limited to the amino acids which were determined quantitatively, but an increase was a general phenomenon. The increase of methionine and $\alpha$-aminobutyric acid, which has been shown to be formed from methionine (11), was particularly prominent. Although cystine was increased in most patients, taurine was not, which indicated that the formation of taurine from cystine was not increased during hepatic coma.

Our observations on the free amino acids in the urine were similar to those of Walshe $(4,5)$ in that those patients with greatly increased free amino acids in the plasma also had increased concentrations of amino acids in the urine.

\section{COMMENT}

Although we observed some abnormalities in the concentrations of amino acids in the plasma of in-

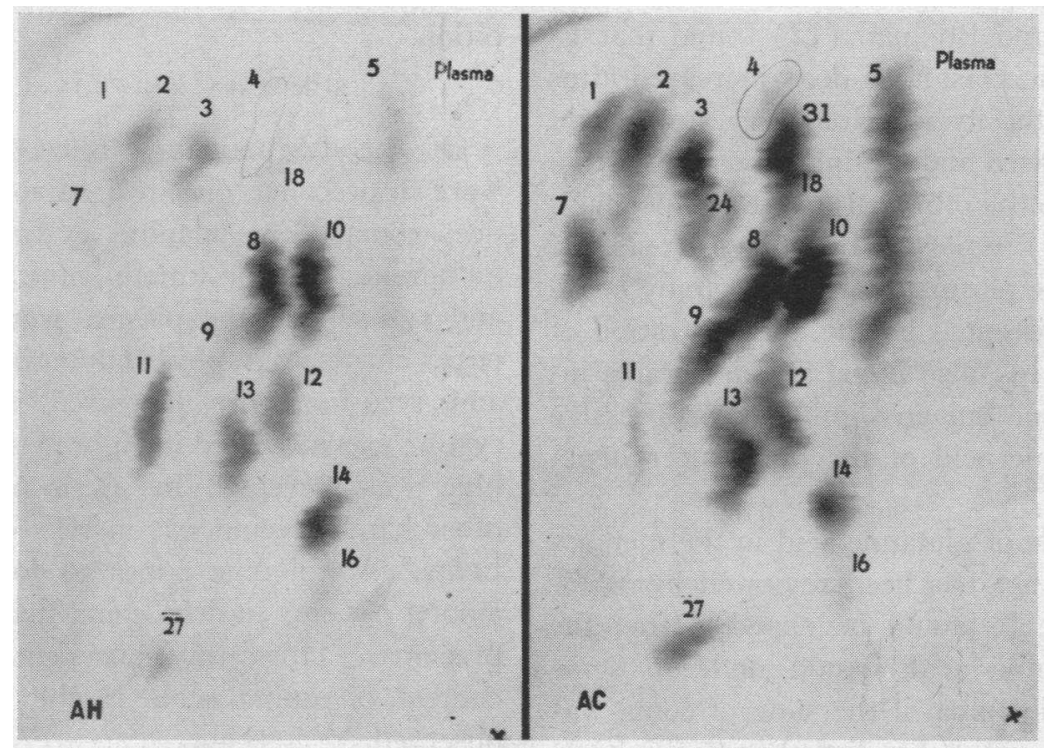

Fig. 1. Chromatograms of Free Amino Acids of the Plasma of a Normal Person (Left) and a Patient (Case 11) in Hepatic Coma (RIGHT)

Aliquots corresponding to 300 microliters of plasma of each were applied to sheets at point $X .1$, phenylalanine; 2 , leucine-isoleucine; 3 , valine; 4 , proline ; 5 , arginine-lysine ; 7 , tyrosine ; 8 , alanine; 9 , threonine; 10 , glutamine; 11 , taurine; 12 , glycine; 13 , serine; 14 , glutamic acid; 16 , aspartic acid; 18 , histidine; 24, $\alpha$-aminobutyric acid; 27, cysteic acid (from cystine); 31, methionine sulfoxide (from methionine). 
dividual patients, consistent findings applicable to all patients were not observed. The plasma of a majority of patients in hepatic coma, however, showed increased concentrations of some of the free amino acids. Furthermore, the increases generally were greater among patients in deep coma than among those in precoma. Walshe (4) observed a gross increase in amino acids among patients in hepatic coma. Later, he (5) showed that the urine of most patients having severe hepatic disease contained increased amounts of many amino acids during hepatic coma; the plasma and the spinal fluid also contained increased concentrations of some of the amino acids. In less severe disease, only the urine showed increased concentrations of amino acids. However, no particular amino acid or groups of amino acids appeared to be specifically increased by hepatic disease or by hepatic coma. Increases in several amino acids usually were found but the changes in each specific amino acid varied from patient to patient. On the other hand, Seegmiller, Schwartz, and Davidson (8) reported that there was no increase in the glutamine contained in the plasma of the patient in hepatic coma.

Flock, Mann, and Bollman (12) found that 15 amino acids in the plasma of dogs increased after total removal of the liver. Not every amino acid was always increased and the increase varied from one amino acid to the other. In a later paper with others, they (13) reported that the increase of amino acids in the plasma after hepatectomy could be reduced or prevented by the administration of glucose. They (14) also noted a considerable increase in glutamine but no significant progressive change in glutamic acid of the brain after hepatectomy.

The central role of glutamic acid in the metabolism of brain tissues has been reviewed by WeilMalherbe (15). It would be expected that the content of glutamic acid should undergo some changes in hepatic coma, if the state of coma was to be related to metabolic disturbances of brain tissues. Our study showed that both glutamic acid and glutamine were increased in a majority of patients during hepatic coma. Walshe (4) suggested that the impaired utilization of glutamic acid may result in failure of intracellular ammonia to be removed from the brain. Although an increase in the concentration of glutamic acid in the plasma was noted, a simultaneous increase in the content of glutamine makes it improbable that the amidation mechanism was impaired. Since the concentration of urea in the blood of many of the patients was normal or high, it is unlikely that the synthesis of urea from ammonia was impaired during hepatic coma.

Our study showed that methionine was significantly increased in a majority of cases. Walshe $(4,5)$ reported the presence of methionine sulfoxide in the cerebrospinal fluid and plasma during hepatic coma. Since methionine is always spontaneously partially oxidized to its sulfoxide during paper chromatography, it appears that the question of whether the sulfoxide is actually present in the spinal fluid and plasma of a patient in hepatic coma cannot be settled by this analytic procedure. It is noteworthy that the increase of methionine was prominent among patients in the last stages of coma.

The presence of increased amounts of methionine, glutamic acid and other amino acids in the plasma of patients in hepatic coma makes it appear unlikely that further additions of these substances would promote recovery from this condition.

\section{SUMMARY AND CONCLUSIONS}

Of the 12 patients observed clinically, four were in precoma, one in light coma, and seven in deep coma. Free alanine, cystine, glutamic acid, glutamine, glycine, methionine, serine, taurine, and tyrosine in the plasma were determined by paper chromatography. Glutamic acid, glutamine, and tyrosine were increased in nine patients; cystine was increased in eight patients, and methionine was increased in seven patients. On the other hand, glycine was increased in only two patients. Methionine appeared to increase oftener among patients in deep coma than among those in precoma. However, consistent changes in the content of amino acids in the plasma were not observed.

\section{REFERENCES}

1. Stadie, W. C., and Vian Slyke, D. D., The effect of acute yellow atrophy on metabolism and on the composition of the liver. Arch. Int. Med., 1920, 25, 693.

2. Snell, A. M., and Butt, H. R., Hepatic coma: Observations bearing on its nature and treatment. Tr. A. Am. Physicians, 1941, 56, 321. 
3. Murphy, T. L., Chalmers, T. C., Eckhardt, R. D., and Davidson, C. S., Hepatic coma: Clinical and laboratory observations on forty patients. New England J. Med., 1948, 239, 605.

4. Walshe, J. M., Observations on the symptomatology and pathogenesis of hepatic coma. Quart. J. Med., 1951, n.s. 20, 421.

5. Walshe, J. M., Disturbances of aminoacid metabolism following liver injury. Quart. J. Med., 1953, n.s. 22, 483.

6. Schwartz, R., Phillips, G. B., Gabuzda, G. J., Jr., and Davidson, C. S., Blood ammonia and electrolytes in hepatic coma. J. Lab. \& Clin. Med., 1953, 42, 499.

7. Traeger, H. S., Gabuzda, G. J., Jr., Ballou, A. N., and Davidson, C. S., Blood "ammonia" concentration in liver disease, and liver coma. Metabolism, 1954, 3, 99.

8. Seegmiller, J. E., Schwartz, R., and Davidson, C. S., The plasma "ammonia" and glutamine content in patients with hepatic coma. J. Clin. Invest., 1954, 33, 984.
9. Bessman, S. P., Fazekas, J. F., and Bessman, A. N., Uptake of ammonia by the brain in hepatic coma. Proc. Soc. Exper. Biol. \& Med., 1954, 85, 66.

10. Wu, C., Metabolism of free amino acids in fasted and zein-fed rats. J. Biol. Chem., 1954, 207, 775.

11. Dent, C. E., Methionine metabolism and A-aminobutyric acid. Science, 1947, 105, 335.

12. Flock, E. V., Mann, F. C., and Bollman, J. L., Free amino acids in plasma and muscle following total removal of the liver. J. Biol. Chem., 1951, 192, 293.

13. Flock, E. V., Block, M. A., Mann, F. C., Grindlay, J. H., and Bollman, J. L., The effect of glucose on the amino acids of plasma after total hepatectomy. J. Biol. Chem., 1952, 198, 427.

14. Flock, E. V., Block, M. A., Grindlay, J. H., Mann, F. C., and Bollman, J. L., Changes in free amino acids of brain and muscle after total hepatectomy. J. Biol. Chem., 1953, 200, 529.

15. Weil-Malherbe, H., Significance of glutamic acid for the metabolism of nervous tissue. Physiol. Rev., 1950, 30, 549. 